\title{
School and Teacher Effects
}

\author{
Stephen L. Morgan \\ Johns Hopkins University \\ Daniel T. Shackelford \\ Johns Hopkins University
}

August 3, 2016

To be published in 2017 as a chapter in

Barbara Schneider, ed.,

Handbook of the Sociology of Education in the 21 $1^{\text {st }}$ Century (Springer)

* Direct correspondence to Stephen L. Morgan (stephen.morgan@jhu.edu) at Department of Sociology, 3400 N. Charles St., Johns Hopkins University, Baltimore, MD 21218 or Daniel T. Shackelford (danielshackelford@jhu.edu) at School of Education, 2800 N. Charles St., Johns Hopkins University, Baltimore, MD 21218. 


\title{
School and Teacher Effects
}

\begin{abstract}
This chapter summarizes the extant sociological literature on the interactive nature of school and teacher effects on student learning. It explains why the most recent literature on teacher sorting demands the attention of more sociologists of education, and it demonstrates what is revealed about patterns of teacher sorting using the type of data most commonly analyzed by sociologists of education. Throughout, the chapter discusses the methodological requirements of research that can and cannot disentangle teacher effects from school effects, and it considers how teacher and school effects may be evolving in the changing landscape of K-12 education in the United States.
\end{abstract}




\section{School and Teacher Effects}

For studies of school performance and student learning, the sociology of education has a long history of research on the effects of teachers. Most of the specific literature on these effects predates the recent push to encourage effective teaching in the United States through accountability policies. In fact, as we will discuss in this chapter, sociologists have contributed very little to the recent debate on the validity of models and measures that seek to identify effective teachers, including methods that (1) infer effective teaching from growth in pupil test scores or (2) assess teacher performance through systematic classroom observation. Instead, these debates have been dominated by economists and policy researchers who have demonstrated little interest in drawing insight from the extant sociological literature on either teacher effects or school effects.

Although the lack of broad engagement among sociologists in the most recent debate on effective teaching might be considered a failing of the sociology of education, it also reflects a healthy skepticism about the worth of engagement in a debate over methods, such as valueadded models (VAMs), thought very likely to fail on their own anyway. Even with this rationalization, now is the time for sociologists to join fellow social scientists and policy researchers in a reconstruction of the literature on teacher effects. Not only is there good reason to expect that the monitoring of effective teaching may have altered the relationships between teachers and other school actors, the debate itself appears to be in a phase transition to more reasonable modes of analysis and interpretation. Scholars of all types seem now to recognize that teacher effects vary fundamentally because of their entanglement with effects generated by 
school and community differences. These encompassing contextual effects are familiar objects of study for sociologists of education, and as a result sociologists have an important contribution to offer.

In this chapter, we have several related aims: (1) to convey the contours of the extant sociological literature on teachers, (2) to consider the interactive nature of school effects and teacher effects on student learning, (3) to explain why the most recent literature, largely outside of sociology, on teacher sorting should receive more attention from sociologists of education, (4) to demonstrate what is revealed about patterns of teacher sorting using the type of data most commonly analyzed by sociologists of education (the most recent nationally representative survey of high school students conducted by the US Department of Education), and (5) to offer our perspective on the methodological and measurement requirements of research that can break new ground on unraveling the interrelationships between school and teacher effects.

\section{Three Themes of Sociological Research on Teachers}

In this section, we recount three prominent themes in sociological research on teachers, which can be discussed in a rough chronological order. No review can hope to be comprehensive, and we aim only to offer examples that demonstrate longstanding sociological engagement on three topics - teachers as professionals embedded in communities, teachers as inputs into student achievement models, and teachers as actors in schools with complex organizational structures that are differentially effective.

Teachers as Professionals Embedded in Communities. The most prominent early sociological research on school teachers is easily identified by the work of Willard Waller, 
whose 1932 book The Sociology of Teaching mapped the contours of subsequent scholarship. To align their work with Waller's legacy, contemporary sociologists still frequently adorn their writing with insightful sentences from Waller's book, most commonly to demonstrate the choppy waters that teachers must navigate when they seek to motivate listless students while accommodating parents and school leaders. Yet, the focus on this single early book in the current collective consciousness often obscures the breadth of related research from early and mid-twentieth century sociology of education. Consider just three examples of topics of study from this period of scholarship that, as we will explain below, remain important to current debates on teacher effectiveness:

1. Professionalism: Teachers should be professionals, and mechanisms for the careful selection and training of teachers need to be further developed (Myers 1934). Teachers differ a great deal in their social origins (Carlson 1961), but they remain valued leaders in their communities (Buck 1960). Teachers retain their community leadership roles partly because their out-of-school behavior is monitored and regulated by the community (Cook, Almack, and Greenhoe 1938; Cook and Greenhoe 1940). Relatedly, teacher satisfaction rests on mutually respectful relations with the community (Roth 1958). In large school systems, teachers move between vacancies in search of students who are easier to teach, typically with the consequence that the schools with students who have the most social disadvantage receive school instruction from the least experienced teachers (Becker 1952a). Fortunately, most teachers remain active readers, including for professional development and the improvement of their own teaching skills (Fisher 1958).

2. Within-Classroom Performance: Teachers are most effective when their social distance from the pupils assigned to them is minimized, suggesting that teachers should be trained and sorted in recognition of these challenges (Bogardus 1928). But because of student heterogeneity, and the lack of an effective system that allocates teachers to students with individual-specific needs, it is important for all teachers to tailor their practices to the individual situations of each student (Bogardus 1929; Becker 1952b). Matching effects aside, teachers who maintain a traditional, autocratic mode of instruction teach more content than do teachers who maintain a congenial, democratic mode of instruction (Brookover 1943). 
3. Attitudes Toward School Leadership: Teachers must navigate conflicting pressures created by students, parents, and principals, and the relationships among teachers reflect their approaches to these pressures (Becker 1953; Gordon 1955). Teacher satisfaction is shaped by whether administrators conform to teachers' expectations of appropriate administrative decision making (Bidwell 1955).

A more comprehensive review of the literature from this period is of limited value, and some of the early research does not meet our current standards of rigor. Nonetheless, some attention is instructive, as these examples demonstrate, to appreciate the provenance of many of the research themes found today in the sociology of education and in debates on teacher effectiveness. Although the three sets of conclusions summarized above range over multiple substantive domains, they are all consistent with the themes set down by Waller: teachers are professionals, pursuing complicated goals, including their own professional development and career trajectories, which must be pursued within schools and communities with diverse actors and dynamic expectations.

Teachers as Inputs in Educational Production. Research on teacher effectiveness was pushed in a new direction by the 1966 study, Equality of Educational Opportunity (EEO), commonly referred to as "the Coleman report" (Coleman et al. 1966). In an attempt to document differences in all schooling "inputs," following on the directive from the Civil Rights Act of 1964 to conduct a national study of educational opportunity, Coleman and his team launched a study of extraordinary importance (see Gamoran and Long 2007; Sørensen and Morgan 2000).

Possibly because of the attention to resource differences across schools, as well as the compelling case made for the preeminence of family background as a determinant of student 
achievement, EEO's attention to the study of teacher effects is often forgotten. In fact, it is not clear that EEO's contributions were ever adequately appreciated. Ravitch (1993:130) claims that its findings on teachers were "almost universally ignored by academic researchers and the press" after the report was released and in subsequent decades. In retrospect, and with another couple of decades of reflection, the core findings of EEO on teacher effects must be recognized as one of sociology's most important contributions to the study of teachers.

For their work, Coleman and his team first tabulate differences in teacher characteristics and skills by the racial identities of students, separately by region of the country. ${ }^{1}$ The overall goal of EEO was to measure and report on such differences. Through linked surveys of students, teachers, and school administrators, Coleman and his team offer the following summaries of their primary findings on teachers (pages 148 and 165, respectively):

Compared to teachers of the average white student, teachers of the average [black student]

- score lower on a test of verbal competence, and the difference is most pronounced in the Southern States.

- $\quad$ are neither more nor less likely to have advanced degrees.

- have slightly more teaching experience, and slightly more tenure in their present school.

- read more professional journals.

- are neither more nor less likely to have majored in an academic subject.

- if they are elementary teachers, were less likely to be trained in teacher's colleges.

- more often are products of colleges that offer no graduate training.

- attended colleges with a much lower percent white in the student body.

- less often rate their college high in academic quality.

- less often are members of academic honorary societies, at least in the South.

- more often participate in teachers' organizations, especially in the South.

- more often have attended institutes for the culturally disadvantaged.

${ }^{1}$ For the specific numbers, see Tables $6 a$ and $6 \mathrm{~b}$, pages 16-17, Tables 2.31 .5 and 2.31.6, pages 124-25, Tables 2.33.1-8, pages 131-40, Tables 2.34.1-14, pages 149-62). 
Compared to the average white [pupil], the average [black] pupil attends a school in which the teachers are

- neither more nor less likely to have high absenteeism rates.

- paid more in some regions and less in others; thus the national averages are about the same.

- more likely to have requested assignment to their particular school and to expect to make a lifelong career of teaching.

- less likely to wish to remain in their present school if given a chance to change, or to declare they would reenter teaching if the decisions could be made again.

- less likely to rate students high on academic motivation and ability.

- less likely to believe that the school has [a] good reputation with other teachers.

- less likely to prefer to teach in an academic high school.

- more likely to spend a substantial amount of time in class preparation.

- more likely to teach large classes.

- more likely to spend time counseling with students.

- somewhat more likely to have taught in the school the prior year

- more likely to take a teacher's examination as a condition of employment.

Racial differences were, therefore, complex when teacher characteristics are analyzed using all

of these measures. The resolution of the complexity for Coleman and his team was to predict student achievement based on teacher characteristics, as part of the larger goal of shifting analysis away from a consideration of equality of inputs toward the capacity of inputs to generate more equality of student outcomes.

Here, the analysis is clear: teacher characteristics are predictive, and more strongly for black students than for white students (see Table 3.25.2 and 3.25.3, page 318). Perhaps most interesting, teachers' verbal test scores (on a thirty item vocabulary test) have independent predictive power, above and beyond teachers' levels of education and experience. For this particular effect, Coleman and his colleagues conclude that "the teachers' verbal skills have a strong effect, first showing at the sixth grade, indicating that between grades 3 and 6 , the verbal skills of the teacher are especially important" (Coleman et al. 1966:318). Altogether, EEO 
concludes that teachers are important, that their effects accumulate over years of schooling, and that the achievement of non-white students is especially responsive to teacher quality.

Because of its design, the Coleman report conceptualized teachers as a schooling "input," reflecting the educational production methodology of the time. In this tradition, school environments are nominally additive, even if the subtlety of the writing sometimes implies genuine interactions. Regardless, in this type of teacher effects research, scholars have less use for characterizations of teachers as professionals embedded in communities, struggling to navigate institutional rules and social relations while working with heterogeneous populations of students. They are seen instead as actors with fixed characteristics and capacities, distributed across schools in ways that reflect their own interests as well as the opportunities and constraints in the labor market for teachers.

Teachers as Members of Differentially Effective Schools. With the maturation of the subfield of sociology of education, scholars continued to work on the three subjects from midtwentieth century work introduced above: professionalism (e.g., Blase 1986), within-classroom performance (e.g., Sieber and Wilder 1967), and attitudes toward the community and school leadership (e.g., Edgar and Warren 1969; Jessup 1978). Some existing questions received deeper examination, such as studies of student-teacher match advantages that leverage higher quality data and refined conceptualizations. Alexander, Entwisle, and Thompson (1987), for example, make the case that pupil-teacher background congruence, based on the match of the 
socioeconomic status of the teacher to that of the pupil's family, promotes higher levels of achievement within the classroom. ${ }^{2}$

The major development, however, was the emergence of a developed perspective on schools as complex organizations. From early work, such as Larkin (1973), Bredo (1977), and Barnett (1984), that explored how school organization determines teacher behavior, a wholeschool approach to modeling effectiveness developed from the 1980s onward. The emergent model came to see teachers not as learning inputs with fixed capacities for generating achievement, with effects variable only according to match differences across students with differing needs, but rather as vital core workers in schools with variable environments that delimit the range of possible performance. From this perspective, teacher effectiveness varies with administrative structures and the social resources that inhere in work networks (see Gamoran, Secada, and Marrett 2000).

This enriched conceptualization of schools emerged from scholarly sources and in response to policy concerns. A preexisting interest in investigating schools as agents of the intergenerational reproduction of inequality was joined to new work on the social organization of schooling (see Hedges and Schneider 2005). The result was increased attention to the unintended and/or hidden consequences of some prominent educational practices, such as ability grouping and curriculum tracking, as well as new consideration of how organizational constraints can limit school functioning and teacher performance. This work was pursued as efforts to desegregate schooling had stalled, the standards-based reform movement was

\footnotetext{
${ }^{2}$ And such studies have continued. Crosnoe, Johnson, Elder (2004), for example, offer evidence of more general achievement gains that result from healthy relationships between students and teachers, which they measure as intergenerational bonding. Now, economists are very much interested in such effects, as we discuss below.
} 
launched in hopes of preserving the international standing of US educational institutions, and whole-school models of reform were initially crafted (later often relabeled "restructuring" and “school turnaround" models; see, e.g., Lee and Smith 1993, 1995).

Much could be written on the development and general contours of the effective schools literature in sociology from the 1980s through 2000, but we focus only briefly on the subset of this literature that has considered the role of teachers in delivering instruction. This literature includes pieces that model teacher commitment, efficacy, and satisfaction as a function of organizational form, leadership structure, and general workplace control (e.g., Bacharach, Bamberger, Conley 1990; Bidwell, Frank, and Quiroz 1997; Ingersoll 1996; Lee, Dedrick, and Smith 1991; Raudenbush, Rowan, and Cheong 1992; Rosenholtz and Simpson 1990; Rowan, Chiang, and Miller 1997). It also includes research that considers the social relations among teachers, and how these relations can be a resource for supporting a school's mission to generate achievement as a collective project (e.g., Bidwell and Yasumoto 1999; Friedkin and Slater 1994; Yasumoto, Uekawa, Bidwell 2001).

Although much variation exists in the particular arguments of these many studies, most valorize the school community's capacity to develop and support effective teaching, even while the specific analysis of teacher practices is not usually a direct subject of study. A good example of this type of argument is the work on private, and especially Catholic, schools. Bryk, Lee, and Holland (1993) is the exemplar. Here, the notion of "subsidiarity" received particular emphasis as a broad ideological commitment that structures effective Catholic schools. As Bryk et al. (1993: 301-02) write: 
... subsidiarity means that the school rejects a purely bureaucratic conception of an organization. There are advantages to workplace specialization, and it is hard to imagine the conduct of complex work without established organizational procedures. Subsidiarity, however, claims that instrumental considerations about work efficiency and specialization must be mediated by a concern for human dignity. Decentralization of school governance is not chosen purely because it is more efficient, although it does appear to have such consequences. Nor is it primarily favored because it creates organizations that are more client sensitive, although this also appears to be true. Rather, decentralization is predicated on the view that personal dignity and human respect are advanced when work is organized in small communities where dialogue and collegiality may flourish. At root is a belief that the full potential of human beings is realized in the social solidarity that can form around these small group associations.

This sort of writing, and explanatory style, is used to explain why Catholic school are effective.

Teachers are central to the mechanism that generates learning, but it is the organization itself that activates the mechanism.

Following the development of this sociological version of the effective schools literature, sociologists have moved toward more direct assessments of interventions that target teacher performance. In some cases, the connections to the effective schools literature are overt (e.g., Gamoran et al. 2003; Moller, Mickelson, Stearns et al. 2013) while for others the attention is less direct (e.g., Hallinan 2008; Jennings and DiPrete 2010). Overall, the effective schools literature remains influential within sociology, and it is an important piece of the foundation on which a prevailing consensus would now appear to rest, and which we detail in the next section.

\section{School Effects and Teacher Effects in Sociology: The Conventional Wisdom in Four}

\section{Propositions}


From the sociological literature on the effects of teachers, we are comfortable asserting that the following propositions are supported by enough convincing evidence to constitute the conventional wisdom of the field:

1. Teacher effects on student learning are real, and these effects vary according to the match of each teacher to each student. ${ }^{3}$

2. Teacher effects are a joint function of teachers' skills and effort, the first of which is strongly shaped by experiences before entering the profession. ${ }^{4}$

3. School environments, which encompass both administrative structures and networks of social relations, shape both student effort and teacher effort.

4. Effective schools align student effort and teacher effort to optimize student learning.

The joint implication of these propositions can be expressed as

$$
\text { Learning }_{i}=f_{i}\left(\text { Teacher }_{j}, \text { Environment }_{s}\right)
$$

where the learning of each student $i$ is an individual-specific function, $f_{i}(\cdot)$, under exposure to a teacher $j$ in school environment $s$. The challenge for analysis is that we typically observe a student's achievement, and possibly a student's achievement growth, for a small number of teachers in only one school. We want to know how learning would differ if each student were exposed to alternative teachers in alternative school environments, after which we could form

\footnotetext{
${ }^{3}$ The recent economics literature, which has leveraged administrative data sources, is also relevant, especially for the claim of match effects. Egalite, Kisida, Winters (2015), for example, show that in Florida the race congruence of student-teacher pairing promotes small but positive effects, even though Winters, Haight, Swaim et al. (2013) argue that gender congruence appears to have no substantial effects. See also Jackson (2013) for a broad treatment of teacher match effects, which demonstrates their importance with empirical results from North Carolina.

${ }^{4}$ The economics literature is also consistent with the skills claim. Ehrenberg and Brewer (1994), analyzing the High School and Beyond data, show that teachers' degrees have positive associations with achievement, perhaps indicating that teacher ability is important. More recently, Clotfelter, Ladd, and Vigdor (2007), through an analysis of North Carolina administrative data, show that teacher experience, test scores, and licensure all have positive associations with achievement, although more for math than for reading. Kukla-Acevedo (2009) show that in a Kentucky school district teachers' math preparation predicted fifth grade math achievement.
} 
estimates for groups of individuals of different types, exposed to different types of teachers and in different school environments. Unfortunately, our observational datasets do not permit clean identification of these effects of interest because the institutional structure of schooling restricts individual students' exposure to alternative teachers and schools.

In sociology, it is common to offer estimated regression equations of the form:

$$
Y=a+\hat{b}_{T} T+\hat{b}_{S} S+\hat{b}_{X} X+e
$$

where $Y$ is a learning outcome measure, $T$ is one or more measures of teacher characteristics, $S$ is one or more measures of school environments, and $X$ is a set of student-level characteristics typically included as "control" variables. The terms such as $\hat{b}_{T}$ are conformable vectors of estimated slope coefficients for the measures specified by the subscripts. If the analysis considers teacher effects directly, then $S$ is often regarded as a set of school-level controls. If the study is one of school environments, in which it is asserted that teacher effects are part of an unobserved mechanism, then $T$ may be excluded, often because suitable measures are unavailable.

Interpretations of results from estimated regression equations of this form are often developed with language that implies interactive effects, such that, for example, the estimates $\hat{b}_{T}$ should be interpreted as conditional on values of $S$, or possibly even $\hat{b}_{S}$. Such interpretations are usually developed as part of the overall conclusions of a study, when authors use theory and intuition to reason beyond their empirical models that usually have been specified as nominally additive. When reasoning beyond the data, few sociologists discuss their findings with explicit recognition of the individual-specific nature of Equation 1, where the function that generates learning is itself individually variable. Instead, individual variability is usually 
thought to have been swept away by a lag specification for the outcome $Y$ along with measures in $X$, even if in some cases the putative teacher effects in $\hat{b}_{T}$ are discussed as if they are conditional on $S$ and $X$. In research where measures in $T$ are unavailable, the reduced form school effects in $\hat{b}_{S}$ are often discussed as if they encompass complex interactions with latent teacher effects, which could be directly estimated were suitable measures in $T$ to become available.

Altogether, in sociology it is widely recognized that the effects of schools and the effects of teachers who work within schools cannot be separated easily in an empirical analysis. Outside of sociology, it is less clear that this point is recognized, as we will discuss below. That said, outside of sociology, especially in the work of economists, it is widely recognized that the joint distribution of students, teachers, and schools generates complex matching gains and deficits in the learning process. This recognition has led to a rich literature on teacher assignment, attrition, and sorting, which we present next.

\section{The Distribution of Teachers Across and Within Schools}

In the past 15 years, since the Elementary and Secondary Education Act was reauthorized by the No Child Left Behind (NCLB) legislation, we have learned a great deal about teacher assignment and teacher sorting. ${ }^{5}$ This research has accumulated progressively, building on

\footnotetext{
${ }^{5}$ We do not mean to imply that scholars did not study assignment and sorting patterns before the era of accountability arrived in the 1990s. One early careful study in sociology is Becker (1952a), as summarized above. And, in the wake of EEO, and after the US Supreme Court ruled that racial balance in the teaching corps is a measure of unitary status in desegregating school districts, scholars became very much interested in the distribution of teachers across schools in the same area. For example, Greenberg and McCall (1974) show that in the San Diego school system teachers sorted across schools based on the socioeconomic status of students, given that the salaries available did not differ across the district.
} 
templates from the 1980s and 1990s of various types (e.g., how teachers respond to desegregation remedies, how teachers are laid off as part of "reductions in force" studies). A growing source of motivation is to understand whether the nation's teaching corps is strong enough, and stable enough, to support a schooling system that will allow the US to remain competitive with the surging economies of international peers. Most recently, as systems were developed by states to consider whether schools were making the adequate yearly progress (AYP) required for continuation under NCLB, some granular analysis of teacher effects across all schools has become possible. The interests of three groups then dovetailed: (1) those who hoped to develop new formulas for AYP that could replace threshold measures of proficiency with alternatives that recognize school differences in average student achievement growth; (2) those who hoped to develop models of achievement growth that could be used to identify teachers who are deserving of merit bonuses; and (3) those who hoped to use achievement growth models to determine the proportion of teachers who are grossly ineffective, yet protected from dismissal because of teacher tenure.

This literature is important for sociologists to absorb because it has implications for the conventional wisdom on school and teacher effects. Yet, it is impossible to review this vast literature both chronologically and by theme in a piece of this length. We have therefore grouped the studies by primary findings, ordered somewhat chronologically as they have been developed in the literature. With only a few exceptions (e.g., Ingersoll 2005; Kalogrides, Loeb, changing their job search choices (see Antos and Rosen 1975; Levinson 1988). 
and Béteille 2012), this research has accumulated in journals that do not have a sociological

focus. The primary findings are:

1. The student composition of schools - percent in poverty, proportion non-white, etc. predicts both teacher attrition and teacher mobility (see Elfers, Plecki, Knapp 2006; Feng 2014; Hanushek, Kain, and Rivkin 2004; Scafidi, Sjoquist, and Stinebrickner 2007). Rates of exit are highest in schools with pupils who have greater social disadvantage, leaving the teaching corps in such schools comparatively young and inexperienced.

2. Across schools in the same geographic region, and frequently the same local education authority, teachers appear to be sorted by the student composition of schools, using standard measures of credentials and experience, and following the pattern first established for teacher attrition (see Allensworth, Ponisciak, Mazzeo 2009; Boyd, Lankford, Loeb et al. 2005; Clotfelter, Ladd, and Vigdor 2005, 2006, 2011; Feng 2010, 2014; Krei 1998; Lankford, Loeb, and Wycoff 2002; Rice 2013).

3. These patterns of teacher attrition, mobility, and sorting may be a response to school management and working conditions, which vary with student composition, rather than a direct response to the greater challenges of teaching students from disadvantaged origins (see Horng 2009; Ingersoll and May 2012; Loeb, Darling-Hammond, and Luczak 2005; Ost and Schiman 2015).

4. Some policy interventions can make between-school sorting even more substantial. These effects have emerged in response to state incentives for hiring certified teachers, merit pay for teachers, class-size reductions, and the passage of accountability legislation (see Clotfelter, Ladd, Vigdor, and Diaz 2004; Goldhaber, Choi, and Cramer 2007; Guarino, Brown, Wise 2011; Jepsen and Rivkin 2009).

5. Salary inducements have not been effective at eliminating teacher sorting across schools, in part because of patterns of racial segregation (see Clotfelter, Ladd, and Vigdor 2011; Feng 2014; Goldhaber, Destler, and Player 2010). Nonetheless, there may be some scope for future change, and more results will be needed to examine the range of policy responses (see Clotfelter, Glennie, Ladd, and Vigdor 2008; Fulbeck 2014; Fulbeck and Richards 2015).

6. Sorting may erode the capacity of resource differences across schools to mitigate the learning differences produced by family background (see Bastian, Henry, Thompson 2013; Ladd 2008; Rubenstein, Schwartz, et al. 2007; but see also Player 2009).

7. Within schools, sorting is also present, following the same pattern of between-school sorting (see Clotfelter, Ladd, and Vigdor 2005, 2006; Feng 2010; Kalogrides, Loeb, and 
Béteille 2012). This finding cannot be surprising to sociologists who know the literature on the assignment of teachers to curriculum tracks.

8. Recent policy interventions have also generated additional sorting within schools, as school leaders have redistributed teachers to satisfy new challenges. For example, Fuller and Ladd (2013) show that in North Carolina, accountability legislation caused schools to move less credentialed teachers down to untested grades (Kindergarten through second grade) and more credentialed teachers up to tested grades (third through fifth grade). Barrett and Toma (2013) show that in ten Kentucky school districts, principals increased class size for teachers they considered effective based on their own assessments.

9. The most recent literature on sorting has been informed by value-added models of teacher effectiveness. VAMs attempt to identify effective teachers by average gains in their pupils' test scores, not measures of teachers' own characteristics or practices. ${ }^{6}$ As of the time of this writing, the implications of the VAM work for teacher sorting results is unclear.

Some studies suggest that teachers with high value-added scores are more likely to remain in their schools (Boyd, Lankford, Loeb et al. 2011), although the pattern is stronger in schools with more advantaged students (Goldhaber, Gross, and Player 2011). ${ }^{7}$ Other studies argue that the latter effects dominate (Steele, Pepper, Springer, Lockwood 2015), with effective teachers more likely to flee schools with larger proportions of students who identify as black (Jackson 2009). Not inconsistent with this pattern, teachers' value-added scores tend to increase after teachers enter new schools (Jackson 2013). Chingos and West (2011) suggest that, in Florida, VAMs indicate that effective teachers are more likely to be promoted to become principals while less effective teachers are more likely to be reassigned to low-stakes positions, consistent with research that does not utilize VAMs to measure effectiveness (see Fuller and Ladd 2013).

Finally, some of the work on teacher sorting that is informed by VAMs has begun to wrestle with school context effects. Koedel (2009) argues that teachers have spillover effects on achievement in subjects that they do not teach while Jackson and Bruegmann (2009) find evidence of spillover effects through peer learning. Loeb, Kalogrides, and Béteille (2012) show that effective schools are able to hire the most

${ }^{6}$ For clear, simple, accurate, and balanced summaries of value added modeling, see Corcoran and Goldhaber (2013) and Corcoran (2016). To understand the required assumptions with more depth, see Reardon and Raudenbush (2009). For studies that have defended and deployed VAMs, see Chetty et al. (2014a, b). For arguments against the use of VAMs, see Rothstein $(2009,2010)$ and Guarino, Reckase, Wooldridge (2015). For work that compares the results of VAMs to various other types of teacher evaluation systems, see Grissom and Youngs (2016).

${ }^{7}$ Jacob and Lefgren (2007) show that parents disproportionately prefer effective teachers in high poverty schools, perhaps because such teachers are comparatively rare. 
effective teachers, as measured by VAMs, while Ferguson and Hirsch (2014) make the case that effective teachers are generated by effective schools.

Overall, the literature on teacher sorting - which now encompasses an older literature on teacher attrition and teacher mobility - raises important questions for sociological research on school and teacher effects. Have we deemphasized the older sociological perspective that conceived of teachers as valuable "inputs" with autonomous capacities to generate learning? Although sociologists have not wavered in their position that "teachers matter," it may be the case that we have been too quick to assume that teachers are broadly similar in their potential, conditional on training, and that variation in any apparent teacher effects is almost entirely attributable to variation in their school environments. Not unrelated to this question, is it possible that schools that appear to be effective because of their administrative structures are instead only effective because they have been better able to attract teachers who are effective because of their own capacities? To begin to address questions such as these, we need to develop a deeper appreciation for the empirics of teachers sorting, and, in the next section, we advance this goal.

\section{An Example of What a Typical Data Source Reveals About the Distribution of Teachers}

Many of the most persuasive studies of teacher assignment and teacher sorting are based on district-level and state-level analyses of administrative, and usually only from states with the most sophisticated data systems that have welcomed academic research. It has been assumed by many researchers that what has been learned in these states is applicable to the nation as a whole, but surely this inference will be evaluated in the future. Furthermore, because of the 
focus on student testing in grades three through eight, in response to NCLB, most studies of teacher sorting consider only elementary schools; those studies that do consider middle school grades have less clear results.

Sociologists of education most commonly study secondary schools, in part because of their longstanding interest in proximate institutions that shape entry into the adult stratification order. Existing teacher effects research in sociology is therefore dominated by studies of high schools. Because of the mismatch with the teacher sorting literature, it is useful to consider what can be learned about teacher sorting from an analysis using the type of data most commonly analyzed by sociologists of education - a national sample of students nested within high schools, collected by the US Department of Education, following on the template first established by Coleman and his colleagues for EEO.

In this chapter, we offer an analysis of the most recent nationally representative survey, which is the High School Longitudinal Survey of 2009 (HSLS). Still ongoing, the HSLS is a sample of first-year public and private high school students in 2009, which includes linked survey instruments for students, parents, math and science teachers, counselors, and school administrators. In this chapter, we consider the distribution of math and science teachers across students in public high schools in 2009, merging to the HSLS data both funding and school characteristics from the 2009 through 2013 Common Core of Data. ${ }^{8}$

\footnotetext{
8 Our analysis is related to, but distinct from, the most common prior analyses of national distributions of teachers. These prior studies, which have been discussed above, have frequently used the Schools and Staffing Surveys (SASS). Analysis of the SASS surveys allows for the modeling of teacher distributions across schools, but not directly of teacher distributions across students, since only school aggregate measures of student characteristics are available, and typically without detailed measures of the family backgrounds of students.
} 
For the HSLS, each sampled first-year high school student is linked, through both an administrative list and a student response, to the teacher of the relevant math and/or science class in which the student was enrolled in fall of 2009. These teachers are then asked to fill in a questionnaire that assesses their class structure, their attitudes toward their school and its students, and their own qualifications.

The 753 public high schools sampled for the HSLS have student samples that range from 7 to 49 students, with a mode of 24 students. These students are matched to both math and science teachers, so that we have a total of 12,832 students matched to 3,172 math teachers and 11,676 students matched to 2,362 science teachers. ${ }^{9}$ When weighted appropriately, the responses of teachers can be used to estimate the distributional characteristics of the teacherstudent match across first-year high school students in 2009 for two linked populations: all students enrolled in math classes in public schools and all students enrolled in science classes in public schools. ${ }^{10}$

We first offer results on school-level climate, where teachers are the informants on the problems that their schools face, as well as teacher satisfaction with the level of support that is provided to meet their challenges. We consider the relationships that teacher-perceived climate and support have with the characteristics of the student populations of HSLS schools, measured by students' socioeconomic status and performance on a standardized math test. We also

\footnotetext{
${ }_{9}^{9}$ On average, we have 4.4 sampled students for each math teacher and 5.4 sampled students for each science teacher, with medians of 3 and 4 students, respectively. At the school level, the median number of math teachers is 4 across the 720 schools with sampled math teachers while the median number of science teachers is 3 across the 699 schools with sampled science teachers.

${ }^{10}$ We exclude private schools from this analysis, mostly because the teacher sorting literature is very much focused on public schools. Of course, teachers do sort into private schools as well, and private schools have served as a valuable point of comparison in the effective schools research in sociology. A more comprehensive analysis should consider sorting by sector and type of school as well.
} 
consider the relationships that teacher-perceived climate and support have with per-pupil instructional expenditures, measured at the district level. This first portion of the analysis establishes the validity of the matched student and teacher samples of the HSLS. We then turn toward an analysis of teachers, consider their preparation and experience, and assess the extent to which a pattern of teacher sorting is present among the math and science teachers of ninth graders.

School Climate as Reported by Teachers. Table 1 presents 32 partial correlation coefficients, bounded by -1 and 1, between the school-level or student-level variable listed in the first row of each panel and each of the teacher-level variables listed in the row labels of each of the subsequent four rows. We offer partial correlation coefficients separately for the reports of math and science teachers, yielding 16 each.

These partial correlation coefficients are estimated by appropriately scaling coefficients form underlying regression models with students nominally as the unit of analysis, and where we adjust the standard errors for the clustering of students within schools and teachers. In addition to specifying each model with one of the two focal variables as the outcome variable and one as a predictor variable (which is arbitrary, given the scaling of the coefficients as partial correlation coefficients), the regression models also include indicator variables for magnet schools and charter schools, with regular public schools as the reference category. The number of magnet and charter schools is too small to permit evaluations of differential associations, and so the indicator variables simply adjust the partial correlation coefficients.

The first panel offers partial correlation coefficients for school mean SES with each of four scales of teacher attitudes about problems at their school. School mean SES is calculated as 
the mean of the sampled students' SES values; each student's value is a standardized composite of the available information on the "big five" variables: mother's and father's education, mother's and father's occupational prestige, and total family income (and where "mother" and "father" are nominal labels in many cases for those who are listed as parents and guardians). The four scales of problems for each teacher are based on agree/disagree responses for multiple underlying questions, which we group together to form the following scales:

Resources and facilities are a problem

- Lack of teacher resources and materials is a problem at this school

- Teaching is limited by shortage of computer hardware/software

- Teaching is limited by shortage of support for using computers

- Teaching is limited by shortage of textbooks for student use

- Teaching is limited by shortage of instructional equipment for students

- Teaching is limited by shortage of equipment for demonstrations

- Teaching is limited by inadequate physical facilities

- Teaching is limited by high student to teacher ratio

Administrative support is a problem

- Teaching is limited by inadequate professional learning opportunities

- Teaching is limited by inadequate administrative support

- Teaching is limited by lack of planning time

- Teaching is limited by lack of autonomy in instructional decisions

Student attitudes and behavior are a problem

- Student tardiness is a problem at this school

- Student absenteeism is a problem at this school

- Student class cutting is a problem at this school

- Students dropping out is a problem at this school

- Student apathy is a problem at this school

- Students coming unprepared to learn is a problem at this school

- Teaching is limited by uninterested students

- Teaching is limited by low morale among students

- Teaching is limited by disruptive students

Lank of parent support is a problem

- Lack of parental involvement is a problem at this school

- Teaching is limited by lack of parent / family support 
All scales are factor scored and have acceptable measurement properties (e.g., Cronbach's alpha estimates of reliability between 0.70 and 0.88 ).

\section{[ INSERT TABLE 1 ABOUT HERE ]}

For the first panel of Table 1, all partial correlation coefficients are in the expected directions, with slightly stronger relationships for math teachers. Schools with more advantaged student populations (i.e., higher values for school mean of SES) have fewer problems according to the teacher reports, with the associations stronger for student and parent attitudes, behavior, and support than for resources, facilities, and administrative support.

How strong are these associations? Like all product-moment correlations, partial correlations are bounded by -1 and 1 . Values for the strongest associations in Table 1 have partial correlation coefficients such as -0.4 , which we interpret as moderately strong, given attenuation from measurement error for each pair of variables. Most of the other associations are much smaller in magnitude, typically near to -0.1 . One might regard these coefficients as too small to be interpreted, but we feel that they are meaningfully negative, usually more than twice the size of their standard errors, and would be larger in magnitude - probably between 25 and 50 percent larger - in the absence of random measurement error.

By our interpretive standards, values that are smaller in magnitude than their standard errors are the only estimated partial correlation coefficients that we think can be reasonably attributed to sampling error alone. Some partial correlation coefficients of this type are present in the second panel. These partial correlation coefficients are for within-school SES measures of each student with the resource and administrative support scales analyzed for the first panel of Table 1. In these cases, individual values for SES are deviated from the school-specific mean, 
and then all schools are pooled for the analysis. Students with high values for within-school SES are those who are well above their school's mean. Given that the teacher attitudes that compose these two scales reference their entire school, we would not expect these partial correlation coefficients to deviate from zero, except as a result of sampling error. That is precisely what we see. ${ }^{11}$ Note that we do have very small negative partial correlation coefficients for the student and parent attitude, behavior, and support scales, suggesting that there is a slight tendency for teachers who are assigned to lower-SES students to report more challenges created by the attitudes and behavior of students and parents.

The third and fourth panels of Table 1 substitute the available HSLS test score for SES, which in this case is a test of algebra knowledge and skill. The values for these two panels are remarkably similar to the first two panels based on SES. The reason is straightforward: SES is strongly associated with the test score, both at the school level and for within-school variation.

Table 2 presents an analogous 32 partial regression coefficients, using the same scales of problems reported by teachers, but using four district-level measure of expenditures. The first panel presents per-pupil instructional expenditures, and the third panel presents per-pupil instructional salary expenditures only. Both measures are drawn from the Common Core of Data, and averaged across the four years during which each student was (or would have been) enrolled in their school. The second and fourth panels are cost-adjusted versions of these two expenditure measures, using the same area-cost-adjustment procedure detailed in Morgan and Jung (2016).

\footnotetext{
11 These within-school scales of SES also have more measurement error, and so the correlation coefficients are further attenuated.
} 


\section{[ INSERT TABLE 2 ABOUT HERE ]}

Whether cost-adjusted or not, schools with higher levels of expenditures have slightly lower levels of teacher-reported problems. The partial correlation coefficients are close to -0.1 in most cases. But, in relative comparisons to the results from Table 1, an interesting difference is present. When considering teacher reports of student and parent attitudes, behavior, and administrative support, the implied associations are substantially weaker than for the school mean of SES and the school mean of test scores. It is unknown whether the relative weakness of these relationships is genuine, or is instead attributable to the necessity of using districtaverage expenditure measures, rather than school-specific measures. Our interpretation is that the relative weakness of the relationships is genuine, since this is what one would expect based on extant research that demonstrates the weak predictive power of expenditures measures of all types (i.e., from EEO to more recent efforts, such as Morgan and Jung 2016). For the other two problems scales - focused explicitly on resources, facilities, and administrator supports - the associations with resources are comparable to those with the school means of SES and test scores. This is also quite sensible, even if the sizes of the relationships between actual resource expenditures and problems attributable to resources and facilities may be smaller than some readers would expect.

Teacher Sorting Across and Within Schools. The results provided in Tables 1 and 2 demonstrate that the HSLS generates reasonable results about how teacher reports of the problems faced by their schools are related to measures of expenditures, test scores, and the SES of students. To assess teacher sorting directly, we now consider teacher characteristics, presenting 24 partial correlation coefficients in each of Tables 3 and 4, analogous to those 
already reported in Tables 1 and 2. Rather than use four scales of teacher-reported problems at their schools, each panel includes three measures of teacher training (whether they have graduate degrees, are certified, and are certified in math or science, respectively) as well as three measures of teacher experience (years since bachelor's degree, years teaching at the current school, and years teaching math or science, respectively, at the high school level).

\section{[ INSERT TABLES 3 AND 4 ABOUT HERE ]}

For Table 3, the partial correlation coefficients for the associations with school mean of SES and school mean of test scores are small but meaningful, and perhaps slightly larger for SES than for test scores. Teachers in high SES schools and with high test scores are slightly more likely to have graduate degrees, be certified, and have more years of teaching experience. In addition, the partial correlation coefficients for within-school SES and within-school test scores are weak but meaningful because they are generally in the expected direction. Students who have comparatively high SES and high test scores in their schools are very slightly more likely to have teachers with stronger training and more experience, with the effect perhaps larger for science teachers than for math teachers. This pattern is consistent with the literature on teacher assignments and curriculum tracking, although perhaps weaker in magnitude than that literature would lead one to expect.

Table 4 presents evidence that schools situated in districts with higher levels of expenditures are also more likely to have teachers with stronger training, and, to a lesser extent, prior experience. The strongest partial correlation coefficients are for graduate degrees among teachers, which may reflect a type of sorting where teachers with graduate degrees choose to work in, or are hired by, school districts with higher expenditures. We do not have data on 
individual teacher salaries, but it seems reasonable that the higher instructional expenditures in these school districts reflect higher salary offers to those hired with graduate degrees, or awarded to those who acquire graduate degrees in the course of their employment within the school district.

Altogether, what have Tables 3 and 4 shown? On the one hand, the associations are all perhaps weaker than one would expect for this type of analysis, given the established literature on teacher sorting and the strong claims that have been developed based on administrative data, usually for elementary schools in selected states. On the other hand, most of the associations are in the expected direction, suggesting that at the high school level, in a national sample, teacher sorting of the typical pattern is present. Sorting is not confined to elementary schools, nor only detectable in states with comparatively rich administrative data that has been made available to academic researchers. ${ }^{12}$

The implication of these patterns is that schools with the highest performance may well benefit from having the strongest teachers (who themselves benefit from higher levels of resources, more supportive administrative structures, and the opportunity to teach students who present fewer learning challenges and have more supportive home environments). Yet, with partial correlations of this magnitude, it is hard to make the case that we have developed evidence that high school teacher sorting is a powerful source of high school differences.

\footnotetext{
${ }_{12}$ In the supplementary appendix, we offer four analogous tables (S1 through S4) for the 10-state saturated sample of schools in the HSLS. For the results reported in these additional tables, we include fixed effects for states in the underlying regression models. The results presented there demonstrate that the average within-state partial correlation coefficients are only slightly smaller in magnitude in nearly all cases of direct comparison to those in Tables 1 through 4, suggesting that these weak patterns of teacher sorting are characteristic of within-state relationships as well. This result implies, even though it is based on an analysis of only 10 states, that the weakness of the associations is not generated by suppression that is attributable to unspecified state-level differences in the results in Tables 1 through 4.
} 
In this sense, the results can be considered somewhat encouraging for the school effects literature in sociology that has mostly ignored sorting dynamics. The caveat, of course, is that this analysis has only rather limited measures of teacher skill and quality. We cannot eliminate the possibility that a more substantial pattern of teacher sorting exists on the characteristics of teachers not measured by the HSLS instrument. And we cannot establish any connections at all to the to the most recent teacher sorting literature, which has used VAMs to attempt to identify effective teachers. It is possible that sorting would appear more dramatic if a valid measure of effectiveness were available, rather than simply measures of qualifications and crude measures of experience.

\section{Conclusions}

In this chapter, we first reviewed the long tradition of sociological research on teacher effects and school effects, with particular emphasis on the interaction between the two. We then considered the large literature on teacher attrition, mobility, and sorting, which has matured mostly outside of sociology. To assess the relevance of the sorting literature to the sociological literature, we then offered an empirical analysis of recent data on high school students and their math and science teachers. We showed that sorting dynamics are present in a national sample of ninth graders matched to their teachers, but we also concluded that the pattern of sorting is not so large that it presents a fundamental challenge to the sociological literature on school effects that typically ignores the dynamics teacher sorting.

We conclude, in this section, with some thoughts on how teacher and school effects are likely to evolve, based on our interpretation of the current policy environment. Partly in 
response to the uncertainty of the value of in-service professional development, as well as the threat of new forms of alternative teacher certification, calls for a more deeply professionalized teaching corps for our public schools are now common. Sociologists will surely study how the teaching profession adapts in the coming decades in response to this new form of teacher mobilization, which seems poised to reshape pre-service teacher training and enhance withinclassroom autonomy. While it may be comforting to believe that these efforts will protect teachers from future evaluation metrics that are too narrow, this prediction may be too sanguine and is certainly premature. We think it is quite plausible that policymakers, administrative authorities, and parents will remain at least as interested in identifying teacher and school effects with simple output measures that can be used to allocate resources and choose from among competing schools. If so, then a new professionalization movement may not alter the relative distribution of teacher effects, by altering sorting patterns, even if the movement does succeed in boosting teacher salaries and improving working conditions.

Changes in the distribution of teacher effects may, however, arise from other sources. As of this writing, the prospects are uncertain for greater harmonization of curricular standards across states, and across school districts within states. If the move toward more common standards receives a new push from a policy shock or leadership change, then the effects of teachers may become easier to discern in studies that analyze comparable criterion-referenced test scores across schools. If these same test scores are to be used for the evaluation of teacher performance, then there is reason to expect a strengthening of the dynamics that generate teacher sorting across schools. In this scenario, apparent school effects may emerge, which in 
fact represent the accentuation of the sorting of effective teachers toward schools with students who are easier to teach.

Consider how any such future sorting dynamics may interact with the most common school effect analyzed recently: the effectiveness of charter schooling. A consensus seems to have emerged (or nearly so) that the highest quality charter schools are no worse than the noncharter alternatives in their vicinity, and frequently substantially better. What has never been effectively determined is how commonly any apparent charter school effects are attributable to (1) their ability to attract higher quality teachers, (2) their ability to motivate teachers of all types to devote substantially more effort, or (3) features of charter schools that are separable from the effects of their teachers, such as disciplinary policy and targeted curricula. If charters schools increase in number, while the velocity of teacher sorting increases, then estimated charter school effects may increase, as teachers, not just students, are creamed from traditional public schools.

Altogether, it will be essential to devote greater attention to developing study designs that can estimate the interactive nature of teacher and school effects, attuned to the underlying processes that determine the job seeking behavior of teachers. The sociological literature on school effects has not considered the distribution of teachers with enough care, even if we can take pride in our greater relative attention to both the organizational context of schooling and the advantages and disadvantages conferred by differences in home environments. The greatest immediate need, however, is not a shift in emphasis on the part of researchers, but rather a new and substantial commitment from federal and state data collection agencies to pursue more complete measurement of the features and activities of students, teachers, and schools. Available administrative data, which has effectively opened up many important 
questions of academic interest and policy importance, does not adequately measure the home environments that strongly shape student performance in school, and offers little granular data on the behavior of students. National data sources, patterned on EEO, are stronger in their measurement of the features of students, their parents, and schools, but they do not include sufficient information on the pedagogy and expertise of teachers or the learning climates within classrooms. Without improvements in available data, nifty new identification strategies from methodologists are unlikely to generate enough insight to enhance our understanding of the complementarities that characterize both school and teacher effects. 


\section{REFERENCES}

Alexander, Karl L., Doris R. Entwisle, and Maxine S. Thompson. 1987. “School Performance, Status Relations, and the Structure of Sentiment: Bringing the Teacher Back In." American Sociological Review 52:665-82.

Allensworth, Elaine, Stephen Ponisciak, and Christopher Mazzeo. 2009. "The Schools Teachers Leave: Teacher Mobility in Chicago Public Schools." Consortium on Chicago School Research at the University of Chicago, Chicago, IL.

Antos, Joseph R. and Sherwin Rosen. 1975. “Discrimination in the Market for Public School Teachers." Journal of Econometrics 3:123-50.

Bacharach, Samuel, Peter Bamberger, and Sharon Conley. 1990. "Professionals and Workplace Control: Organizational and Demographic Models of Teacher Militancy." Industrial and Labor Relations Review 43:570-86.

Barnett, Bruce G. 1984. "Subordinate Teacher Power in School Organizations." Sociology of Education 57:43-55.

Barrett, Nathan and Eugenia F. Toma. 2013. "Reward or Punishment? Class Size and Teacher Quality." Economics of Education Review 35:41-52.

Bastian, Kevin C., Gary T. Henry, and Charles L. Thompson. 2013. "Incorporating Access to More Effective Teachers into Assessments of Educational Resource Equity." Education Finance and Policy 8:560-80.

Becker, Howard S. 1952a. "The Career of the Chicago Public Schoolteacher." American Journal of Sociology 57:470-77.

-. 1952b. "Social-Class Variations in the Teacher-Pupil Relationship." The Journal of Educational Sociology 25:451-65.

-. 1953. "The Teacher in the Authority System of the Public School." The Journal of Educational Sociology 27:128-41.

Bidwell, Charles E. 1955. "The Administrative Role and Satisfaction in Teaching." The Journal of Educational Sociology 29:41-47.

Bidwell, Charles E., Kenneth A. Frank, and Pamela A. Quiroz. 1997. “Teacher Types, Workplace Controls, and the Organization of Schools." Sociology of Education 70:285-307.

Bidwell, Charles E. and Jeffrey Y. Yasumoto. 1999. “The Collegial Focus: Teaching Fields, Collegial Relationships, and Instructional Practice in American High Schools." Sociology of Education 72:234-56.

Blase, Joseph J. 1986. "Socialization as Humanization: One Side of Becoming a Teacher." Sociology of Education 59:100-13.

Bogardus, Emory S. 1928. "Teaching and Social Distance." The Journal of Educational Sociology 1:595-98. 
-. 1929. "Social Case Analysis and Teaching." The Journal of Educational Sociology 3:3-6.

Boyd, Don, Hamp Lankford, Susanna Loeb, Matthew Ronfeldt, and Jim Wyckoff. 2011. “The Role of Teacher Quality in Retention and Hiring: Using Applications to Transfer to Uncover Preferences of Teachers and Schools." Journal of Policy Analysis and Management 30:88-110.

Boyd, Donald, Hamilton Lankford, Susanna Loeb, and James Wyckoff. 2005. "Explaining the Short Careers of High-Achieving Teachers in Schools with Low-Performing Students." The American Economic Review 95:166-71.

Bredo, Eric. 1977. “Collaborative Relations among Elementary School Teachers.” Sociology of Education 50:300-09.

Brookover, Wilbur. 1943. "The Social Roles of Teachers and Pupil Achievement." American Sociological Review 8:389-93.

Buck, Roy C. 1960. “The Extent of Social Participation among Public School Teachers.” The Journal of Educational Sociology 33:311-19.

Bryk, Anthony S., Valerie E. Lee, and Peter B. Holland. 1993. Catholic Schools and the Common Good. Cambridge: Harvard University Press.

Carlson, Richard O. 1961. "Variation and Myth in the Social Status of Teachers." The Journal of Educational Sociology 35:104-18.

Chetty, Raj, John N. Friedman, and Jonah E. Rockoff. 2014. "Measuring the Impacts of Teachers I: Evaluating Bias in Teacher Value-Added Estimates." American Economic Review 104:2593-632.

-. 2014. "Measuring the Impacts of Teachers Ii: Teacher Value-Added and Student Outcomes in Adulthood." American Economic Review 104:2633-79.

Chingos, Matthew M. and Martin R. West. 2011. "Promotion and Reassignment in Public School Districts: How Do Schools Respond to Differences in Teacher Effectiveness?" Economics of Education Review 30:419-33.

Clotfelter, Charles T., Helen F. Ladd, and Jacob Vigdor. 2005. "Who Teaches Whom? Race and the Distribution of Novice Teachers." Economics of Education Review 24:377-92.

Clotfelter, Charles T., Helen F. Ladd, and Jacob L. Vigdor. 2006. "Teacher-Student Matching and the Assessment of Teacher Effectiveness." The Journal of Human Resources 41:778-820.

-. 2007. "Teacher Credentials and Student Achievement: Longitudinal Analysis with Student Fixed Effects." Economics of Education Review 26:673-82.

-. 2011. “Teacher Mobility, School Segregation, and Pay-Based Policies to Level the Playing Field." Education Finance and Policy 6:399-438.

Clotfelter, Charles T., Helen F. Ladd, Jacob L. Vigdor, and Roger Aliaga Diaz. 2004. “Do School Accountability Systems Make It More Difficult for Low-Performing Schools to Attract and Retain High-Quality Teachers?" Journal of Policy Analysis and Management 23:251-71. 
Coleman, James S., Ernest Q. Campbell, Carol J. Hobson, James McPartland, Alexander M. Mood, Frederick D. Weinfeld et al. 1966. Equality of Educational Opportunity. Washington, DC: U.S. Department of Health, Education, and Welfare, Office of Education.

Cook, Lloyd A., Ronald B. Almack, and Florence Greenhoe. 1938. “Teacher and Community Relations." American Sociological Review 3:167-74.

Cook, Lloyd A. and Florence Greenhoe. 1940. "Community Contacts of 9,122 Teachers." Social Forces 19:63-72.

Corcoran, Sean and Dan Goldhaber. 2013. "Value Added and Its Uses: Where You Stand Depends on Where You Sit." Education Finance and Policy 8:418-34.

Corcoran, Sean P. 2016. "Potential Pitfalls in the Use of Teacher Value-Added Data." Pp. 51-62 in Improving Teacher Evaluation Systems: Making the Most of Multiple Measures, edited by J. A. Grissom and P. Youngs. New York: Teachers College Press.

Crosnoe, Robert, Monica Kirkpatrick Johnson, and Glen H. Elder. 2004. “Intergenerational Bonding in School: The Behavioral and Contextual Correlates of Student-Teacher Relationships." Sociology of Education 77:60-81.

Edgar, Donald E. and Richard L. Warren. 1969. "Power and Autonomy in Teacher Socialization." Sociology of Education 42:386-99.

Egalite, Anna J., Brian Kisida, and Marcus A. Winters. 2015. "Representation in the Classroom: The Effect of Own-Race Teachers on Student Achievement." Economics of Education Review 45:44-52.

Ehrenberg, Ronald G. and Dominic J. Brewer. 1994. “Do School and Teacher Characteristics Matter? Evidence from High School and Beyond." Economics of Education Review 13:1-17.

Elfers, Ana M., Margaret L. Plecki, and Michael S. Knapp. 2006. “Teacher Mobility: Looking More Closely at "the Movers" within a State System." Peabody Journal of Education 81:94127.

Feng, Li. 2010. “Hire Today, Gone Tomorrow: New Teacher Classroom Assignments and Teacher Mobility." Education Finance and Policy 5:278-316.

-. 2014. “Teacher Placement, Mobility, and Occupational Choices after Teaching." Education Economics 22:24-47.

Ferguson, Ronald F. and Eric Hirsch. 2014. "How Working Conditions Predict Teaching Quality and Student Outcomes." Pp. 332-80 in Designing Teacher Evaluation Systems: New Guidance from the Measures of Effective Teaching Project, edited by T. J. Kane, K. A. Kerr, and R. C. Pianta. San Francisco, CA: Jossey-Bass.

Fisher, Helen. 1958. “Teachers Reading Habits: A Sign of Professional Interest." The Journal of Educational Sociology 32:127-32.

Friedkin, Noah E. and Michael R. Slater. 1994. "School Leadership and Performance: A Social Network Approach." Sociology of Education 67:139-57. 
Fulbeck, Eleanor S. 2014. "Teacher Mobility and Financial Incentives: A Descriptive Analysis of Denver's Procomp." Educational Evaluation and Policy Analysis 36:67-82.

Fulbeck, Eleanor S. and Meredith P. Richards. 2015. “The Impact of School-Based Financial Incentives on Teachers' Strategic Moves: A Descriptive Analysis." Teachers College Record 117:1-36.

Fuller, Sarah C. and Helen F. Ladd. 2013. "School-Based Accountability and the Distribution of Teacher Quality across Grades in Elementary School." Education Finance and Policy 8:52859.

Gamoran, Adam, Charles W. Anderson, Walter G. Secada, Tona Williams, and Scott Ashmann. 2003. Transforming Teaching in Math and Science: How Schools and Districts Can Support Change. New York: Teachers College Press.

Gamoran, Adam and Daniel A. Long. 2007. “Equality of Educational Opportunity: A 40 Year Retrospective." Pp. 23-47 in International Studies in Educational Inequality, Theory and Policy, edited by R. Teese, S. Lamb, M. Duru-Bellat, and S. Helme: Springer Netherlands.

Gamoran, Adam, Walter G. Secada, and Cora B. Marrett. 2000. "The Organizational Context of Teaching and Learning: Changing Theoretical Perspectives." Pp. 37-63 in Handbook of the Sociology of Education, edited by M. T. Hallinan. New York: Kluwer/Plenum.

Goldhaber, Dan, Hyung-Jai Choi, and Lauren Cramer. 2007. "A Descriptive Analysis of the Distribution of NBTPS-Certified Teachers in North Carolina." Economics of Education Review 26:160-72.

Goldhaber, Dan, Katharine Destler, and Daniel Player. 2010. "Teacher Labor Markets and the Perils of Using Hedonics to Estimate Compensating Differentials in the Public Sector." Economics of Education Review 29:1-17.

Goldhaber, Dan, Betheny Gross, and Daniel Player. 2011. "Teacher Career Paths, Teacher Quality, and Persistence in the Classroom: Are Public Schools Keeping Their Best?" Journal of Policy Analysis and Management 30:57-87.

Gordon, C. Wayne. 1955. "The Role of the Teacher in the Social Structure of the High School." The Journal of Educational Sociology 29:21-29.

Greenberg, David and John McCall. 1974. "Teacher Mobility and Allocation.” The Journal of Human Resources 9:480-502.

Grissom, Jason A. and Peter Youngs, Eds. 2016. Improving Teacher Evaluation Systems: Making the Most of Multiple Measures. New York, NY: Teachers College Press.

Guarino, Cassandra M., Abigail B. Brown, and Adam E. Wyse. 2011. “Can Districts Keep Good Teachers in the Schools That Need Them Most?" Economics of Education Review 30:962-79.

Guarino, Cassandra M., Mark D. Reckase, and Jeffrey M. Wooldridge. 2014. “Can Value-Added Measures of Teacher Performance Be Trusted?" Education Finance and Policy 10:117-56.

Hallinan, Maureen T. 2008. “Teacher Influences on Students' Attachment to School.” Sociology of Education 81:271-83. 
Hanushek, Eric A., John F. Kain, and Steven G. Rivkin. 2004. “Why Public Schools Lose Teachers." The Journal of Human Resources 39:326-54.

Hedges, Larry V. and Barbara L. Schneider, Eds. 2005. The Social Organization of Schooling. New York: Russell Sage Foundation.

Horng, Eileen Lai. 2009. "Teacher Tradeoffs: Disentangling Teachers' Preferences for Working Conditions and Student Demographics." American Educational Research Journal 46:690717.

Ingersoll, Richard M. 1996. "Teachers' Decision-Making Power and School Conflict." Sociology of Education 69:159-76.

- . 2005. "The Problem of Underqualified Teachers: A Sociological Perspective." Sociology of Education 78:175-78.

Ingersoll, Richard M. and Henry May. 2012. "The Magnitude, Destinations, and Determinants of Mathematics and Science Teacher Turnover." Educational Evaluation and Policy Analysis 34:435-64.

Jackson, C. Kirabo. 2009. “Student Demographics, Teacher Sorting, and Teacher Quality: Evidence from the End of School Desegregation." Journal of Labor Economics 27:213-56.

-. 2013. "Match Quality, Worker Productivity, and Worker Mobility: Direct Evidence from Teachers." Review of Economics and Statistics 95:1096-116.

Jackson, C. Kirabo and Elias Bruegmann. 2009. “Teaching Students and Teaching Each Other: The Importance of Peer Learning for Teachers." American Economic Journal: Applied Economics 1:85-108.

Jacob, Brian A. and Lars Lefgren. 2007. “What Do Parents Value in Education? An Empirical Investigation of Parents' Revealed Preferences for Teachers." The Quarterly Journal of Economics 122:1603-37.

Jennings, Jennifer L. and Thomas A. DiPrete. 2010. “Teacher Effects on Social and Behavioral Skills in Early Elementary School." Sociology of Education 83:135-59.

Jepsen, Christopher and Steven Rivkin. 2009. "Class Size Reduction and Student Achievement: The Potential Tradeoff between Teacher Quality and Class Size." The Journal of Human Resources 44:223-50.

Jessup, Dorothy K. 1978. “Teacher Unionization: A Reassessment of Rank and File Motivations." Sociology of Education 51:44-55.

Kalogrides, Demetra, Susanna Loeb, and Tara Béteille. 2013. "Systematic Sorting: Teacher Characteristics and Class Assignments." Sociology of Education 86:103-23.

Koedel, Cory. 2009. "An Empirical Analysis of Teacher Spillover Effects in Secondary School." Economics of Education Review 28:682-92.

Krei, Melinda Scott. 1998. "Intensifying the Barriers: The Problem of Inequitable Teacher Allocation in Low-Income Urban Schools." Urban Education 33:71-94. 
Kukla-Acevedo, Sharon. 2009. “Do Teacher Characteristics Matter? New Results on the Effects of Teacher Preparation on Student Achievement." Economics of Education Review 28:49-57.

Ladd, Helen F. 2008. "Reflections on Equity, Adequacy, and Weighted Student Funding." Education Finance and Policy 3:402-23.

Lankford, Hamilton, Susanna Loeb, and James Wyckoff. 2002. "Teacher Sorting and the Plight of Urban Schools: A Descriptive Analysis." Educational Evaluation and Policy Analysis 24:37-62.

Larkin, Ralph W. 1973. “Contextual Influences on Teacher Leadership Styles.” Sociology of Education 46:471-79.

Lee, Valerie E., Robert F. Dedrick, and Julia B. Smith. 1991. “The Effect of the Social Organization of Schools on Teachers' Efficacy and Satisfaction." Sociology of Education 64:190-208.

Lee, Valerie E. and Julia B. Smith. 1993. “Effects of School Restructuring on the Achievement and Engagement of Middle-Grade Students." Sociology of Education 66:164-87.

Lee, Valerie E. and Julia B. Smith. 1995. “Effects of High School Restructuring and Size on Early Gains in Achievement and Engagement." Sociology of Education 68:241-70.

Levinson, Arik M. 1988. "Reexamining Teacher Preferences and Compensating Wages." Economics of Education Review 7:357-64.

Loeb, Susanna, Linda Darling-Hammond, and John Luczak. 2005. “How Teaching Conditions Predict Teacher Turnover in California Schools." Peabody Journal of Education 80:44-70.

Loeb, Susanna, Demetra Kalogrides, and Tara Béteille. 2012. “Effective Schools: Teacher Hiring, Assignment, Development, and Retention." Education Finance and Policy 7:269-304.

Moller, Stephanie, Roslyn Arlin Mickelson, Elizabeth Stearns, Neena Banerjee, and Martha Cecilia Bottia. 2013. "Collective Pedagogical Teacher Culture and Mathematics Achievement: Differences by Race, Ethnicity, and Socioeconomic Status." Sociology of Education 86:174-94.

Morgan, Stephen L. and Sol Bee Jung. 2016. "Still No Effect of Resources, Even in the New Gilded Age?" Russell Sage Foundation Journal of the Social Sciences 2:83-116.

Myers, Alonzo F. 1934. "Education of Teachers for the Schools of Tomorrow." The Journal of Educational Sociology 7:569-74.

Ost, Ben and Jeffrey C. Schiman. 2015. "Grade-Specific Experience, Grade Reassignments, and Teacher Turnover." Economics of Education Review 46:112-26.

Player, Daniel. 2009. "Monetary Returns to Academic Ability in the Public Teacher Labor Market." Economics of Education Review 28:277-85.

Raudenbush, Stephen W., Brian Rowan, and Yuk Fai Cheong. 1992. "Contextual Effects on the Self-Perceived Efficacy of High School Teachers." Sociology of Education 65:150-67.

Ravitch, Diane. 1993. "The Coleman Reports and American Education." Pp. 129-41 in Social 
Theory and Social Policy: Essays in Honor of James S. Coleman, edited by A. B. Sørensen and S. Spilerman. Westport: Praeger.

Reardon, Sean F. and Stephen W. Raudenbush. 2009. "Assumptions of Value-Added Models for Estimating School Effects." Education Finance and Policy 4:492-519.

Rice, Jennifer King. 2013. "Learning from Experience? Evidence on the Impact and Distribution of Teacher Experience and the Implications for Teacher Policy." Education Finance and Policy 8:332-48.

Rosenholtz, Susan J. and Carl Simpson. 1990. “Workplace Conditions and the Rise and Fall of Teachers' Commitment." Sociology of Education 63:241-57.

Roth, Lester J. 1958. “Occupational Analysis and Teacher Morale." The Journal of Educational Sociology 32:145-51.

Rothstein, Jesse. 2009. "Student Sorting and Bias in Value-Added Estimation: Selection on Observables and Unobservables." Education Finance and Policy 4:537-71.

Rothstein, Jesse. 2010. “Teacher Quality in Educational Production: Tracking, Decay, and Student Achievement." The Quarterly Journal of Economics 125:175-214.

Rowan, Brian, Fang-Shen Chiang, and Robert J. Miller. 1997. “Using Research on Employees' Performance to Study the Effects of Teachers on Students' Achievement." Sociology of Education 70:256-84.

Rubenstein, Ross, Amy Ellen Schwartz, Leanna Stiefel, and Hella Bel Hadj Amor. 2007. “From Districts to Schools: The Distribution of Resources across Schools in Big City School Districts." Economics of Education Review 26:532-45.

Scafidi, Benjamin, David L. Sjoquist, and Todd R. Stinebrickner. 2007. "Race, Poverty, and Teacher Mobility." Economics of Education Review 26:145-59.

Sieber, Sam D. and David E. Wilder. 1967. "Teaching Styles: Parental Preferences and Professional Role Definitions." Sociology of Education 40:302-15.

Sørensen, Aage B. and Stephen L. Morgan. 2000. "School Effects: Theoretical and Methodological Issues." Pp. 137-60 in Handbook of the Sociology of Education, edited by M. T. Hallinan. New York: Kluwer/Plenum.

Steele, Jennifer L., Matthew J. Pepper, Matthew G. Springer, and J. R. Lockwood. 2015. “The Distribution and Mobility of Effective Teachers: Evidence from a Large, Urban School District." Economics of Education Review 48:86-101.

Waller, Willard. 1932. The Sociology of Teaching. New York: Wiley.

Winters, Marcus A., Robert C. Haight, Thomas T. Swaim, and Katarzyna A. Pickering. 2013. "The Effect of Same-Gender Teacher Assignment on Student Achievement in the Elementary and Secondary Grades: Evidence from Panel Data." Economics of Education Review 34:69-75.

Yasumoto, Jeffrey Y., Kazuaki Uekawa, and Charles E. Bidwell. 2001. “The Collegial Focus and 
High School Students' Achievement." Sociology of Education 74:181-209. 
Table 1. Partial Correlation Coefficients for Students' Socioeconomic Status and Algebra Test Scores in the Ninth Grade with Teachers' Reports of Resource Problems and Climate Problems

\begin{tabular}{|c|c|c|c|c|}
\hline & \multicolumn{2}{|c|}{ Math Teacher } & \multicolumn{2}{|c|}{ Science Teacher } \\
\hline & $\begin{array}{c}\text { Partial } \\
\text { Correlation }\end{array}$ & $\begin{array}{c}\text { Standard } \\
\text { Error }\end{array}$ & $\begin{array}{c}\text { Partial } \\
\text { Correlation }\end{array}$ & $\begin{array}{c}\text { Standard } \\
\text { Error }\end{array}$ \\
\hline \multicolumn{5}{|l|}{ School Mean of SES with } \\
\hline Resources and facilities are a problem & -0.138 & 0.035 & -0.052 & 0.032 \\
\hline Administrative support is a problem & -0.098 & 0.029 & 0.056 & 0.034 \\
\hline Student attitudes and behavior are a problem & -0.385 & 0.028 & -0.328 & 0.031 \\
\hline Lack of parent support is a problem & -0.403 & 0.027 & -0.384 & 0.030 \\
\hline \multicolumn{5}{|l|}{ Within-School SES with } \\
\hline Resources and facilities are a problem & -0.003 & 0.013 & 0.003 & 0.017 \\
\hline Administrative support is a problem & 0.007 & 0.014 & -0.002 & 0.015 \\
\hline Student attitudes and behavior are a problem & -0.020 & 0.013 & -0.015 & 0.013 \\
\hline Lack of parent support is a problem & -0.030 & 0.013 & -0.033 & 0.014 \\
\hline \multicolumn{5}{|l|}{ School Mean of Algebra Test Score with } \\
\hline Resources and facilities are a problem & -0.163 & 0.032 & -0.091 & 0.035 \\
\hline Administrative support is a problem & -0.101 & 0.030 & 0.014 & 0.038 \\
\hline Student attitudes and behavior are a problem & -0.380 & 0.028 & -0.352 & 0.030 \\
\hline Lack of parent support is a problem & -0.360 & 0.029 & -0.382 & 0.032 \\
\hline \multicolumn{5}{|l|}{ Within-School Algebra Test Score with } \\
\hline Resources and facilities are a problem & -0.010 & 0.015 & -0.001 & 0.023 \\
\hline Administrative support is a problem & 0.024 & 0.017 & 0.032 & 0.023 \\
\hline Student attitudes and behavior are a problem & -0.040 & 0.015 & -0.015 & 0.018 \\
\hline Lack of parent support is a problem & -0.034 & 0.016 & -0.015 & 0.016 \\
\hline
\end{tabular}

Source: High School Longitudinal Study of 2009 (HSLS:09)

Notes: The partial correlation coefficients are adjusted for school type (whether the high school is a charter or magnet school), and the data are weighted to the populations of ninth graders enrolled in math and science classes, respectively. The standard errors are heteroskedasticity-consistent and are adjusted for the clustering of students within teachers. 
Table 2. Partial Correlation Coefficients for District-Level Per Pupil Expenditures with Teachers' Reports of Resource Problems and Climate Problems

\begin{tabular}{|c|c|c|c|c|}
\hline & \multicolumn{2}{|c|}{ Math Teacher } & \multicolumn{2}{|c|}{ Science Teacher } \\
\hline & $\begin{array}{c}\text { Partial } \\
\text { Correlation }\end{array}$ & $\begin{array}{l}\text { Standard } \\
\text { Error }\end{array}$ & $\begin{array}{c}\text { Partial } \\
\text { Correlation }\end{array}$ & $\begin{array}{l}\text { Standard } \\
\text { Error }\end{array}$ \\
\hline \multicolumn{5}{|l|}{ All Instructional Expenditures (per pupil) with } \\
\hline Resources and facilities are a problem & -0.104 & 0.030 & -0.035 & 0.055 \\
\hline Administrative support is a problem & -0.036 & 0.034 & 0.049 & 0.049 \\
\hline Student attitudes and behavior are a problem & -0.077 & 0.035 & -0.088 & 0.042 \\
\hline Lack of parent support is a problem & -0.078 & 0.035 & -0.081 & 0.036 \\
\hline \multicolumn{5}{|l|}{$\begin{array}{l}\text { All Instructional Expenditures (per pupil and } \\
\text { cost-adjusted) with }\end{array}$} \\
\hline Resources and facilities are a problem & -0.097 & 0.029 & -0.056 & 0.055 \\
\hline Administrative support is a problem & -0.050 & 0.034 & 0.010 & 0.049 \\
\hline Student attitudes and behavior are a problem & -0.075 & 0.035 & -0.092 & 0.042 \\
\hline Lack of parent support is a problem & -0.060 & 0.035 & -0.055 & 0.040 \\
\hline \multicolumn{5}{|l|}{$\begin{array}{l}\text { Instructional Salary Expenditures (per pupil) } \\
\text { with }\end{array}$} \\
\hline Resources and facilities are a problem & -0.125 & 0.031 & -0.058 & 0.049 \\
\hline Administrative support is a problem & -0.054 & 0.032 & 0.044 & 0.047 \\
\hline Student attitudes and behavior are a problem & -0.106 & 0.033 & -0.108 & 0.039 \\
\hline Lack of parent support is a problem & -0.111 & 0.033 & -0.101 & 0.035 \\
\hline \multicolumn{5}{|l|}{$\begin{array}{l}\text { Instructional Salary Expenditures (per pupil } \\
\text { and cost-adjusted) with }\end{array}$} \\
\hline Resources and facilities are a problem & -0.121 & 0.028 & -0.082 & 0.050 \\
\hline Administrative support is a problem & -0.071 & 0.031 & 0.003 & 0.046 \\
\hline Student attitudes and behavior are a problem & -0.104 & 0.034 & -0.111 & 0.040 \\
\hline Lack of parent support is a problem & -0.093 & 0.033 & -0.070 & 0.037 \\
\hline
\end{tabular}

Source: See Table 1.

Notes: See Table 1. 
Table 3. Partial Correlation Coefficients for Students' Socioeconomic Status and Algebra Test Scores in the Ninth Grade with Teachers' Training and Experience

\begin{tabular}{|c|c|c|c|c|}
\hline & \multicolumn{2}{|c|}{ Math Teacher } & \multicolumn{2}{|c|}{ Science Teacher } \\
\hline & $\begin{array}{c}\text { Partial } \\
\text { Correlation }\end{array}$ & $\begin{array}{c}\text { Standard } \\
\text { Error }\end{array}$ & $\begin{array}{c}\text { Partial } \\
\text { Correlation }\end{array}$ & $\begin{array}{c}\text { Standard } \\
\text { Error }\end{array}$ \\
\hline \multicolumn{5}{|l|}{ School Mean of SES with } \\
\hline Teacher has a graduate degree & 0.095 & 0.030 & 0.096 & 0.031 \\
\hline Teacher is certified & 0.070 & 0.035 & 0.109 & 0.033 \\
\hline Teacher is certified in math/science & 0.076 & 0.034 & 0.105 & 0.032 \\
\hline Years since bachelor's degree & 0.003 & 0.028 & 0.048 & 0.033 \\
\hline Years at current school & 0.079 & 0.029 & 0.077 & 0.032 \\
\hline Years teaching math/science in high school & 0.051 & 0.027 & 0.114 & 0.030 \\
\hline \multicolumn{5}{|l|}{ Within-School SES with } \\
\hline Teacher has a graduate degree & 0.015 & 0.012 & 0.025 & 0.014 \\
\hline Teacher is certified & 0.036 & 0.014 & 0.015 & 0.012 \\
\hline Teacher is certified in math/science & 0.042 & 0.014 & 0.020 & 0.013 \\
\hline Years since bachelor's degree & 0.039 & 0.012 & 0.032 & 0.014 \\
\hline Years at current school & 0.032 & 0.013 & 0.027 & 0.013 \\
\hline Years teaching math/science in high school & 0.038 & 0.013 & 0.030 & 0.013 \\
\hline \multicolumn{5}{|l|}{ School Mean of Algebra Test Score with } \\
\hline Teacher has a graduate degree & 0.083 & 0.029 & 0.099 & 0.033 \\
\hline Teacher is certified & 0.058 & 0.037 & 0.138 & 0.034 \\
\hline Teacher is certified in math/science & 0.065 & 0.036 & 0.132 & 0.034 \\
\hline Years since bachelor's degree & 0.003 & 0.028 & 0.066 & 0.037 \\
\hline Years at current school & 0.084 & 0.027 & 0.073 & 0.034 \\
\hline Years teaching math/science in high school & 0.047 & 0.025 & 0.099 & 0.033 \\
\hline \multicolumn{5}{|l|}{ Within-School Algebra Test Score with } \\
\hline Teacher has a graduate degree & 0.051 & 0.015 & 0.040 & 0.015 \\
\hline Teacher is certified & 0.060 & 0.016 & 0.027 & 0.022 \\
\hline Teacher is certified in math/science & 0.064 & 0.016 & 0.036 & 0.022 \\
\hline Years since bachelor's degree & 0.068 & 0.015 & 0.023 & 0.016 \\
\hline Years at current school & 0.076 & 0.016 & 0.038 & 0.014 \\
\hline Years teaching math/science in high school & 0.085 & 0.016 & 0.032 & 0.015 \\
\hline
\end{tabular}

Source: See Table 1.

Notes: See Table 1. 
Table 4. Partial Correlation Coefficients for District-Level Per Pupil Expenditures with Teachers' Training and Experience

\begin{tabular}{|c|c|c|c|c|}
\hline & \multicolumn{2}{|c|}{ Math Teacher } & \multicolumn{2}{|c|}{ Science Teacher } \\
\hline & $\begin{array}{c}\text { Partial } \\
\text { Correlation }\end{array}$ & $\begin{array}{l}\text { Standard } \\
\text { Error }\end{array}$ & $\begin{array}{c}\text { Partial } \\
\text { Correlation }\end{array}$ & $\begin{array}{l}\text { Standard } \\
\text { Error }\end{array}$ \\
\hline \multicolumn{5}{|l|}{ All Instructional Expenditures (per pupil) with } \\
\hline Teacher has a graduate degree & 0.151 & 0.026 & 0.161 & 0.037 \\
\hline Teacher is certified & 0.056 & 0.032 & 0.013 & 0.043 \\
\hline Teacher is certified in math/science & 0.061 & 0.032 & 0.018 & 0.042 \\
\hline Years since bachelor's degree & 0.020 & 0.027 & 0.038 & 0.041 \\
\hline Years at current school & 0.061 & 0.035 & 0.101 & 0.039 \\
\hline Years teaching math/science in high school & -0.002 & 0.032 & 0.028 & 0.031 \\
\hline \multicolumn{5}{|l|}{$\begin{array}{l}\text { All Instructional Expenditures (per pupil and } \\
\text { cost-adjusted) with }\end{array}$} \\
\hline Teacher has a graduate degree & 0.115 & 0.028 & 0.127 & 0.040 \\
\hline Teacher is certified & 0.065 & 0.032 & 0.018 & 0.047 \\
\hline Teacher is certified in math/science & 0.069 & 0.032 & 0.021 & 0.047 \\
\hline Years since bachelor's degree & 0.016 & 0.028 & 0.028 & 0.044 \\
\hline Years at current school & 0.077 & 0.036 & 0.139 & 0.041 \\
\hline Years teaching math/science in high school & 0.012 & 0.031 & 0.055 & 0.033 \\
\hline \multicolumn{5}{|l|}{$\begin{array}{l}\text { Instructional Salary Expenditures (per pupil) } \\
\text { with }\end{array}$} \\
\hline Teacher has a graduate degree & 0.144 & 0.025 & 0.160 & 0.033 \\
\hline Teacher is certified & 0.059 & 0.033 & 0.030 & 0.039 \\
\hline Teacher is certified in math/science & 0.066 & 0.033 & 0.034 & 0.039 \\
\hline Years since bachelor's degree & 0.006 & 0.027 & 0.026 & 0.036 \\
\hline Years at current school & 0.058 & 0.034 & 0.083 & 0.038 \\
\hline Years teaching math/science in high school & 0.005 & 0.028 & 0.020 & 0.031 \\
\hline \multicolumn{5}{|l|}{$\begin{array}{l}\text { Instructional Salary Expenditures (per pupil } \\
\text { and cost-adjusted) with }\end{array}$} \\
\hline Teacher has a graduate degree & 0.110 & 0.027 & 0.125 & 0.036 \\
\hline Teacher is certified & 0.071 & 0.032 & 0.036 & 0.045 \\
\hline Teacher is certified in math/science & 0.076 & 0.031 & 0.039 & 0.044 \\
\hline Years since bachelor's degree & 0.004 & 0.028 & 0.015 & 0.040 \\
\hline Years at current school & 0.074 & 0.035 & 0.125 & 0.040 \\
\hline Years teaching math/science in high school & 0.020 & 0.030 & 0.048 & 0.032 \\
\hline
\end{tabular}

Source: See Table 1.

Notes: See Table 1. 


\section{SUPPLEMENTARY APPENDIX}

for

School and Teacher Effects

Stephen L. Morgan

Johns Hopkins University

Daniel T. Shackelford

Johns Hopkins University 
Table S1. Within-State Partial Correlation Coefficients for Students' Socioeconomic Status and Algebra Test Scores in the Ninth Grade with Teachers' Reports of Resource Problems and Climate Problems

\begin{tabular}{|c|c|c|c|c|}
\hline & \multicolumn{2}{|c|}{ Math Teacher } & \multicolumn{2}{|c|}{ Science Teacher } \\
\hline & $\begin{array}{c}\text { Partial } \\
\text { Correlation }\end{array}$ & $\begin{array}{c}\text { Standard } \\
\text { Error }\end{array}$ & $\begin{array}{c}\text { Partial } \\
\text { Correlation }\end{array}$ & $\begin{array}{c}\text { Standard } \\
\text { Error }\end{array}$ \\
\hline \multicolumn{5}{|l|}{ School Mean of SES with } \\
\hline Resources and facilities are a problem & -0.138 & 0.040 & -0.083 & 0.045 \\
\hline Administrative support is a problem & -0.054 & 0.042 & 0.056 & 0.044 \\
\hline Student attitudes and behavior are a problem & -0.314 & 0.044 & -0.272 & 0.042 \\
\hline Lack of parent support is a problem & -0.349 & 0.037 & -0.337 & 0.043 \\
\hline \multicolumn{5}{|l|}{ Within-School SES with } \\
\hline Resources and facilities are a problem & 0.002 & 0.017 & -0.021 & 0.018 \\
\hline Administrative support is a problem & 0.025 & 0.019 & -0.031 & 0.018 \\
\hline Student attitudes and behavior are a problem & -0.008 & 0.019 & -0.015 & 0.018 \\
\hline Lack of parent support is a problem & -0.025 & 0.020 & -0.040 & 0.020 \\
\hline \multicolumn{5}{|l|}{ School Mean of Algebra Test Score with } \\
\hline Resources and facilities are a problem & -0.135 & 0.039 & -0.118 & 0.048 \\
\hline Administrative support is a problem & -0.095 & 0.039 & -0.041 & 0.042 \\
\hline Student attitudes and behavior are a problem & -0.401 & 0.039 & -0.345 & 0.045 \\
\hline Lack of parent support is a problem & -0.355 & 0.040 & -0.364 & 0.052 \\
\hline Within-School Algebra Test Score with & -0.005 & 0.023 & -0.017 & 0.022 \\
\hline Resources and facilities are a problem & 0.056 & 0.024 & 0.016 & 0.025 \\
\hline Administrative support is a problem & -0.024 & 0.022 & -0.025 & 0.022 \\
\hline Student attitudes and behavior are a problem & -0.018 & 0.023 & -0.024 & 0.023 \\
\hline Lack of parent support is a problem & -0.005 & 0.023 & -0.017 & 0.022 \\
\hline
\end{tabular}

Source: See Table 1.

Notes: See Table 2. 
Table S2. Within-State Partial Correlation Coefficients for District-Level Per Pupil Expenditures with Teachers' Reports of Resource Problems and Climate Problems

\begin{tabular}{|c|c|c|c|c|}
\hline & \multicolumn{2}{|c|}{ Math Teacher } & \multicolumn{2}{|c|}{ Science Teacher } \\
\hline & $\begin{array}{c}\text { Partial } \\
\text { Correlation }\end{array}$ & $\begin{array}{l}\text { Standard } \\
\text { Error }\end{array}$ & $\begin{array}{c}\text { Partial } \\
\text { Correlation }\end{array}$ & $\begin{array}{c}\text { Standard } \\
\text { Error }\end{array}$ \\
\hline \multicolumn{5}{|l|}{ All Instructional Expenditures (per pupil) with } \\
\hline Resources and facilities are a problem & -0.104 & 0.039 & -0.130 & 0.047 \\
\hline Administrative support is a problem & -0.090 & 0.037 & -0.056 & 0.068 \\
\hline Student attitudes and behavior are a problem & -0.005 & 0.048 & -0.075 & 0.049 \\
\hline Lack of parent support is a problem & 0.003 & 0.037 & -0.138 & 0.059 \\
\hline \multicolumn{5}{|l|}{$\begin{array}{l}\text { All Instructional Expenditures (per pupil and } \\
\text { cost-adjusted) with }\end{array}$} \\
\hline Resources and facilities are a problem & -0.068 & 0.046 & -0.139 & 0.048 \\
\hline Administrative support is a problem & -0.108 & 0.044 & -0.114 & 0.062 \\
\hline Student attitudes and behavior are a problem & -0.008 & 0.052 & -0.092 & 0.052 \\
\hline Lack of parent support is a problem & 0.016 & 0.044 & -0.071 & 0.073 \\
\hline \multicolumn{5}{|l|}{$\begin{array}{l}\text { Instructional Salary Expenditures (per pupil) } \\
\text { with }\end{array}$} \\
\hline Resources and facilities are a problem & -0.113 & 0.036 & -0.132 & 0.048 \\
\hline Administrative support is a problem & -0.118 & 0.036 & -0.033 & 0.053 \\
\hline Student attitudes and behavior are a problem & -0.009 & 0.041 & -0.088 & 0.048 \\
\hline Lack of parent support is a problem & -0.010 & 0.036 & -0.138 & 0.051 \\
\hline \multicolumn{5}{|l|}{$\begin{array}{l}\text { Instructional Salary Expenditures (per pupil } \\
\text { and cost-adjusted) with }\end{array}$} \\
\hline Resources and facilities are a problem & -0.081 & 0.040 & -0.139 & 0.052 \\
\hline Administrative support is a problem & -0.135 & 0.041 & -0.096 & 0.059 \\
\hline Student attitudes and behavior are a problem & -0.008 & 0.047 & -0.099 & 0.054 \\
\hline Lack of parent support is a problem & 0.008 & 0.043 & -0.063 & 0.062 \\
\hline
\end{tabular}

Source: See Table 1.

Notes: See Table 2. 
Table S3. Within-State Partial Correlation Coefficients for Students' Socioeconomic Status and Algebra Test Scores in the Ninth Grade with Teachers' Training and Experience

\begin{tabular}{|c|c|c|c|c|}
\hline & \multicolumn{2}{|c|}{ Math Teacher } & \multicolumn{2}{|c|}{ Science Teacher } \\
\hline & $\begin{array}{c}\text { Partial } \\
\text { Correlation }\end{array}$ & $\begin{array}{c}\text { Standard } \\
\text { Error }\end{array}$ & $\begin{array}{c}\text { Partial } \\
\text { Correlation }\end{array}$ & $\begin{array}{c}\text { Standard } \\
\text { Error }\end{array}$ \\
\hline \multicolumn{5}{|l|}{ School Mean of SES with } \\
\hline Teacher has a graduate degree & 0.093 & 0.041 & 0.067 & 0.046 \\
\hline Teacher is certified & 0.007 & 0.046 & 0.082 & 0.054 \\
\hline Teacher is certified in math/science & 0.023 & 0.047 & 0.076 & 0.053 \\
\hline Years since bachelor's degree & -0.004 & 0.039 & 0.056 & 0.050 \\
\hline Years at current school & -0.008 & 0.038 & 0.056 & 0.041 \\
\hline Years teaching math/science in high school & 0.009 & 0.034 & 0.092 & 0.043 \\
\hline \multicolumn{5}{|l|}{ Within-School SES with } \\
\hline Teacher has a graduate degree & 0.021 & 0.018 & 0.040 & 0.018 \\
\hline Teacher is certified & 0.029 & 0.022 & 0.018 & 0.019 \\
\hline Teacher is certified in math/science & 0.041 & 0.022 & 0.028 & 0.019 \\
\hline Years since bachelor's degree & 0.050 & 0.018 & 0.009 & 0.019 \\
\hline Years at current school & 0.049 & 0.021 & 0.011 & 0.016 \\
\hline Years teaching math/science in high school & 0.041 & 0.020 & 0.003 & 0.018 \\
\hline \multicolumn{5}{|l|}{ School Mean of Algebra Test Score with } \\
\hline Teacher has a graduate degree & 0.112 & 0.041 & 0.099 & 0.048 \\
\hline Teacher is certified & 0.032 & 0.050 & 0.137 & 0.052 \\
\hline Teacher is certified in math/science & 0.051 & 0.048 & 0.133 & 0.052 \\
\hline Years since bachelor's degree & 0.005 & 0.040 & 0.113 & 0.054 \\
\hline Years at current school & 0.030 & 0.034 & 0.068 & 0.038 \\
\hline Years teaching math/science in high school & 0.032 & 0.032 & 0.085 & 0.039 \\
\hline \multicolumn{5}{|l|}{ Within-School Algebra Test Score with } \\
\hline Teacher has a graduate degree & 0.068 & 0.022 & 0.054 & 0.020 \\
\hline Teacher is certified & 0.064 & 0.025 & 0.040 & 0.020 \\
\hline Teacher is certified in math/science & 0.072 & 0.024 & 0.051 & 0.020 \\
\hline Years since bachelor's degree & 0.079 & 0.023 & 0.031 & 0.022 \\
\hline Years at current school & 0.100 & 0.025 & 0.056 & 0.019 \\
\hline Years teaching math/science in high school & 0.102 & 0.025 & 0.029 & 0.021 \\
\hline
\end{tabular}

Source: See Table 1.

Notes: The sample is limited to ten states for which the school samples are representative (but the identity of the specific states is only available to restricted-access HSLS:09 users). The standard errors are heteroskedasticity-consistent and are adjusted for the clustering of students within teachers. The partial correlation coefficients are adjusted for school type (whether the high school is a charter or magnet school) as well as state, and the data are weighted to the populations of ninth graders enrolled in math and science classes, respectively. Because of the inclusion of nine state dummies in the underling regression models, the partial correlations are interpretable as estimates of within-state relationships for the pooled ten-state sample. 
Table S4. Within-State Partial Correlation Coefficients for District-Level Per Pupil Expenditures with Teachers' Training and Experience

\begin{tabular}{|c|c|c|c|c|}
\hline & \multicolumn{2}{|c|}{ Math Teacher } & \multicolumn{2}{|c|}{ Science Teacher } \\
\hline & $\begin{array}{c}\text { Partial } \\
\text { Correlation }\end{array}$ & $\begin{array}{l}\text { Standard } \\
\text { Error }\end{array}$ & $\begin{array}{c}\text { Partial } \\
\text { Correlation }\end{array}$ & $\begin{array}{l}\text { Standard } \\
\text { Error }\end{array}$ \\
\hline \multicolumn{5}{|l|}{ All Instructional Expenditures (per pupil) with } \\
\hline Teacher has a graduate degree & 0.050 & 0.037 & -0.009 & 0.042 \\
\hline Teacher is certified & 0.026 & 0.030 & 0.063 & 0.046 \\
\hline Teacher is certified in math/science & 0.027 & 0.030 & 0.065 & 0.045 \\
\hline Years since bachelor's degree & 0.090 & 0.035 & 0.048 & 0.048 \\
\hline Years at current school & 0.011 & 0.034 & 0.016 & 0.042 \\
\hline Years teaching math/science in high school & 0.005 & 0.033 & 0.011 & 0.043 \\
\hline \multicolumn{5}{|l|}{$\begin{array}{l}\text { All Instructional Expenditures (per pupil and } \\
\text { cost-adjusted) with }\end{array}$} \\
\hline Teacher has a graduate degree & -0.040 & 0.037 & -0.077 & 0.044 \\
\hline Teacher is certified & -0.004 & 0.040 & 0.037 & 0.055 \\
\hline Teacher is certified in math/science & 0.000 & 0.106 & 0.037 & 0.054 \\
\hline Years since bachelor's degree & 0.063 & 0.042 & 0.027 & 0.057 \\
\hline Years at current school & 0.036 & 0.037 & 0.070 & 0.059 \\
\hline Years teaching math/science in high school & 0.009 & 0.041 & 0.026 & 0.054 \\
\hline \multicolumn{5}{|l|}{$\begin{array}{l}\text { Instructional Salary Expenditures (per pupil) } \\
\text { with }\end{array}$} \\
\hline Teacher has a graduate degree & 0.081 & 0.035 & 0.024 & 0.040 \\
\hline Teacher is certified & 0.016 & 0.030 & 0.087 & 0.047 \\
\hline Teacher is certified in math/science & 0.020 & 0.030 & 0.088 & 0.046 \\
\hline Years since bachelor's degree & 0.075 & 0.036 & 0.060 & 0.040 \\
\hline Years at current school & 0.030 & 0.035 & 0.037 & 0.039 \\
\hline Years teaching math/science in high school & 0.027 & 0.035 & 0.031 & 0.039 \\
\hline \multicolumn{5}{|l|}{$\begin{array}{l}\text { Instructional Salary Expenditures (per pupil } \\
\text { and cost-adjusted) with }\end{array}$} \\
\hline Teacher has a graduate degree & -0.014 & 0.036 & -0.062 & 0.048 \\
\hline Teacher is certified & -0.008 & 0.037 & 0.057 & 0.058 \\
\hline Teacher is certified in math/science & -0.003 & 0.036 & 0.056 & 0.057 \\
\hline Years since bachelor's degree & 0.059 & 0.043 & 0.040 & 0.054 \\
\hline Years at current school & 0.055 & 0.037 & 0.096 & 0.053 \\
\hline Years teaching math/science in high school & 0.032 & 0.041 & 0.048 & 0.050 \\
\hline
\end{tabular}

Source: See Table 1.

Notes: See Table 2. 
Table S5. Partial Correlation Coefficients for Students' Socioeconomic Status, Algebra Test Scores, and District-Level Per Pupil Expenditures with School Administrators' Reports of Climate Problems

\begin{tabular}{|c|c|c|}
\hline & $\begin{array}{c}\text { Partial } \\
\text { Correlation }\end{array}$ & $\begin{array}{l}\text { Standard } \\
\text { Error }\end{array}$ \\
\hline \multicolumn{3}{|l|}{ School Mean of SES with } \\
\hline Frequency of abuse and disrespect of teachers & -0.117 & 0.052 \\
\hline Frequency of other student deviance & -0.033 & 0.054 \\
\hline Student attitudes and behavior are a problem & -0.388 & 0.043 \\
\hline \multicolumn{3}{|l|}{ School Mean of Algebra Test Score with } \\
\hline Frequency of abuse and disrespect of teachers & -0.162 & 0.055 \\
\hline Frequency of other student deviance & -0.036 & 0.059 \\
\hline Student attitudes and behavior are a problem & -0.366 & 0.045 \\
\hline \multicolumn{3}{|l|}{ All Instructional Expenditures (per pupil) with } \\
\hline Frequency of abuse and disrespect of teachers & -0.025 & 0.063 \\
\hline Frequency of other student deviance & -0.150 & 0.045 \\
\hline Student attitudes and behavior are a problem & -0.009 & 0.059 \\
\hline \multicolumn{3}{|l|}{$\begin{array}{l}\text { All Instructional Expenditures (per pupil and } \\
\text { cost-adjusted) with }\end{array}$} \\
\hline Frequency of abuse and disrespect of teachers & -0.043 & 0.062 \\
\hline Frequency of other student deviance & -0.219 & 0.051 \\
\hline Student attitudes and behavior are a problem & 0.012 & 0.056 \\
\hline \multicolumn{3}{|l|}{$\begin{array}{l}\text { Instructional Salary Expenditures (per pupil) } \\
\text { with }\end{array}$} \\
\hline Frequency of abuse and disrespect of teachers & 0.002 & 0.059 \\
\hline Frequency of other student deviance & -0.148 & 0.047 \\
\hline Student attitudes and behavior are a problem & -0.029 & 0.058 \\
\hline \multicolumn{3}{|l|}{$\begin{array}{l}\text { Instructional Salary Expenditures (per pupil } \\
\text { and cost-adjusted) with }\end{array}$} \\
\hline Frequency of abuse and disrespect of teachers & -0.020 & 0.058 \\
\hline Frequency of other student deviance & -0.222 & 0.055 \\
\hline Student attitudes and behavior are a problem & -0.006 & 0.055 \\
\hline
\end{tabular}

Source: See Table 1.

Notes: See Table 1. 
Table S6. Within-State Partial Correlation Coefficients for Students' Socioeconomic Status, Algebra Test Scores, and District-Level Per Pupil Expenditures with School Administrators' Reports of Climate Problems

\begin{tabular}{|c|c|c|}
\hline & $\begin{array}{c}\text { Partial } \\
\text { Correlation }\end{array}$ & $\begin{array}{l}\text { Standard } \\
\text { Error }\end{array}$ \\
\hline \multicolumn{3}{|l|}{ School Mean of SES with } \\
\hline Frequency of abuse and disrespect of teachers & -0.244 & 0.081 \\
\hline Frequency of other student deviance & -0.054 & 0.074 \\
\hline Student attitudes and behavior are a problem & -0.383 & 0.059 \\
\hline \multicolumn{3}{|l|}{ School Mean of Algebra Test Score with } \\
\hline Frequency of abuse and disrespect of teachers & -0.251 & 0.090 \\
\hline Frequency of other student deviance & -0.082 & 0.081 \\
\hline Student attitudes and behavior are a problem & -0.371 & 0.062 \\
\hline \multicolumn{3}{|l|}{ All Instructional Expenditures (per pupil) with } \\
\hline Frequency of abuse and disrespect of teachers & 0.019 & 0.083 \\
\hline Frequency of other student deviance & -0.021 & 0.087 \\
\hline Student attitudes and behavior are a problem & 0.116 & 0.081 \\
\hline \multicolumn{3}{|l|}{$\begin{array}{l}\text { All Instructional Expenditures (per pupil and } \\
\text { cost-adjusted) with }\end{array}$} \\
\hline Frequency of abuse and disrespect of teachers & -0.019 & 0.078 \\
\hline Frequency of other student deviance & -0.131 & 0.083 \\
\hline Student attitudes and behavior are a problem & 0.131 & 0.090 \\
\hline \multicolumn{3}{|l|}{$\begin{array}{l}\text { Instructional Salary Expenditures (per pupil) } \\
\text { with }\end{array}$} \\
\hline Frequency of abuse and disrespect of teachers & 0.018 & 0.077 \\
\hline Frequency of other student deviance & -0.039 & 0.076 \\
\hline Student attitudes and behavior are a problem & 0.084 & 0.073 \\
\hline \multicolumn{3}{|l|}{$\begin{array}{l}\text { Instructional Salary Expenditures (per pupil } \\
\text { and cost-adjusted) with }\end{array}$} \\
\hline Frequency of abuse and disrespect of teachers & -0.021 & 0.072 \\
\hline Frequency of other student deviance & -0.154 & 0.079 \\
\hline Student attitudes and behavior are a problem & 0.103 & 0.078 \\
\hline
\end{tabular}

Source: See Table 1.

Notes: See Table 2. 